\title{
PENERAPAN TEKNIK KONTRASTIF DALAM MENULIS TEGAK BERSAMBUNG PADA SISWA KELAS 1 SEKOLAH DASAR KABUPATEN MADIUN
}

\author{
Nur Samsiyah \\ Universitas PGRI Madiun, agsya_cahaya@yahoo.co.id
}

\begin{abstract}
Based on the observation in the classroom, upright writing skillsis less desirable for students. This is known in the implementation of writing the value of students is still low and many are still less tidy or not in accordance with the spelling. This research attempts to apply contrastive techniques in upright writing skills. The formulation of the problem, namely: (1) how is the activity of writing writing upright with the application of contrastive techniques to the students of grade 1 elementary school in Madiun Regency ?; And (2) how the students' learning outcomes in writing upright with the implementation of the technique of contrastive. in grade 1 elementary school students in Madiun Regency? The purpose of this research is to describe the activity and the result of learning to write upright with continuous technique. This research is a qualitative research to know the application of contrastive technique in learning writing. The research data is the 1st grader of SD in Madiun Regency. The method used to collect data in the form of observation and test.
\end{abstract}

Keywords: contrastive technique, upright writing skills

\section{PENDAHULUAN}

Menulis merupakan suatu kegiatan untuk menciptakan suatu catatan atau informasi pada suatu media dengan menggunakan aksara (Alex dan Ahmad, 2011: 106). Selanjutnya Henry Guntur Tarigan (2008: 22) berpendapat bahwa menulis ialah menurunkan atau melukiskan lambang-lambang grafik yang menggambarkan suatu bahasa yang dipahami oleh seseorang, sehingga orangorang lain dapat membaca lambang-lambang grafik tersebut kalau mereka memahami bahasa dan gambaran grafik itu.

Selain itu, menulis juga merupakan suatu aktivitas komunikasi yang menggunakan bahasa sebagai medianya. Wujudnya berupa tulisan yang terdiri atas rangkaian huruf yang bermakna dengan semua kelengkapannya, seperti ejaan 
dan tanda baca. Menulis juga suatu proses penyampaian gagasan, pesan, sikap, dan pendapat kepada pembaca dengan simbol-simbol atau lambang bahasa yang dapat dilihat dan disepakati bersama oleh penulis dan pembaca.

Permasalahan yang sering terjadi dalam pembelajaran bahasa adalah ketika seorang siswa harus mampu menguasai keterampilan menulis tegak bersambung. Menulis tegak bersambung kelihatan menjadi sangat sukar bagi mereka yang memiliki bakat, minat, dan keterampilan menulis yang pas-pasan. Untuk memahami keterampilan menulis tegak bersambung diperlukan latihan dan bentuk pembelajaran yang menarik dan mudah dipahami. Teknik menulis yang digunakan oleh siswa masih banyak yang mengikuti huruf lepas sehingga siswa kelas 1 kesulitan dalam mengingat huruf dan menyambung.

Untuk itu, guru perlu mempêrkenalkan model pembelajaran yang dapat menjadikan suasana belajar siswa yang menyenangkan dan lebih efektif, dengan harapan kondisi kegiatan belajar siswa akan lebih nyaman (menikmati) sesuai dengan keinginan belajar siswa. Dengan memperkenalkan model pembelajaran yang dapat melibatkan semua siswa untuk aktif dalam kegiatan belajar, pencapaian tujuan pembelajaran akan lebih efektif dan hasil kegiatan pembelajaran akan lebih nyata hasilnya. Menurut Hamalik (2001:75) Guru dituntut untuk memiliki kemampuan mendesain programnya dan sekaligus menentukan strtegi intruksional yang harus ditempuh. Para guru harus memiliki keterampilan dalam mengajar khususnya mengajar menulis tegak bersambung. Salah satu teknik yang dapat digunakan adalah teknik kontrastif, yaitu teknik dengan membandingkan dan membedakan huruf agar siswa lebih mudah mengingat huruf terlebih dahulu.Bagaimana aktivitas dan hasil belajar dan pembelajaran bahasa dengan penerapan teknik kontrastif untuk materi menulis tegak bersambung pada siswa kelas I Sekolah Dasar di Kabupaten Madiun? 
Nur Samsiyah, Penerapan Teknik... (hlm. 91-103)

\section{Hakikat Menulis}

Suparno dan dan Yunus (2003: 1.3) mengemukakan bahwa menulis dapat didefinisikan sebagai suatu kegiatan penyampaian pesan (komunikasi) dengan menggunakan bahasa tulis sebagai alat atau medianya. Henry Guntur Tarigan (2008: 3) berpendapat bahwa menulis merupakan suatu keterampilan berbahasa yang dipergunakan untuk berkomunikasi secara tidak langsung, tidak secara tatap muka dengan orang lain.Menulis, menurut Crimmon (dalam St.Y. Slamet 2008: 96) adalah kegiatan menggali pikiran dan perasaan mengenai suatu subjek, memilih hal-hal yang akan ditulis, menentukan cara menuliskannya sehingga pembaca dapat memahaminya dengan mudah dan jelas. Supriadi (1977 :17) menjelaskan bahwa "menulis merupakan suatu proses kreatif yang banyak melibatkan cara berfikir divergen (menyebar) daripada konvergen (memusat)". Sedangkan Purwanto (1977:58) menjelaskan bahwa menulis adalah melahirkan pikiran dan perasaan dengan cara teratur .

Kegiatan menulis merupakan keterampilan mekanis yang dapat dipahami dan dipelajari. Menulis sebagai suatu proses terdiri atas beberapa tahapan. Tompkins (1994) dan Ellis dkk. (1989) menguraikan lima tahapan menulis, yaitu pra-menulis, pengedrafan, perbaikan, penyuntingan, dan publikasi. Pada pramenulis, siswa diberi kesempatan menentukan apa yang akan ditulis, tujuan menulis, dan kerangka tulisan. Setelah siswa menentukan apa yang akan ditulis dan sistematika tulisan, siswa mengumpulkan bahan-bahan tulisan dengan menggunakan buku-buku dan sumber lainnya untuk memudahkan dalam penulisan. Pada pengedrafan, siswa dibimbing menuangkan gagasan, pikiran, dan perasaannya dalam bentuk draf kasar. Pada tahap perbaikan, siswa merevisi draf yang telah disusun. Siswa dapat meminta bantuan guru maupun teman sekelas untuk membantu dan mempertimbangkan gagasan yang dikemukakan. Pada tahap penyuntingan, siswa dilatih untuk memperbaiki aspek mekanik (ejaan, tanda baca, pilihan kata, dan 
struktur kalimat) yang tidak sesuai dengan kaidah penulisan. Hal ini dilakukan untuk memperbaiki karangan sendiri maupun teman sekelas. Pada tahap publikasi, siswa menyampaikan tulisan kepada teman sekelas untuk meminta masukan dari guru dan teman sekelas agar mereka dapat berbagi informasi sehingga tulisan menjadi sempurna.

Keterampilan menulis merupakan satu keterampilan yang ditunjukkan oleh siswa bahwa ia bukan buta aksara. Pelatihan menulis menyibukan para siswa belajar bahasa. Semua ulangan selalu dinyatakan dalam bentuk tulis. Walaupun demikian, para guru masih mengeluhkan bahwa masih ada siswa tidak mempunyai keterampilan menulis.

Parera dan Tasai (1995:14) mengemukakan bahwa untuk dapat menetralisir keluhan para guru bahasa, maka perlu diingatkan mereka dua fakta. Fakta yang pertama banyak sekali orang pandai sangat lemah dalam keterampilan menulis, fakta kedua, hanya sekelompok kecil orang yang dapat menulis dengan baik setelah lama berlatih di sekolah dan di luar sekolah. Walaupun demikian keterampilan menulis merupakan satu keterampilan yang harus diajarkan dan perhatikan dalam pembelajaran bahasa meskipun dalam bentuk sederhana.

Beberapa jenjang untuk keterampilan menurut Parera dan Tasai (1995:15) adalah: (1) menyalin naskah dalam bahasa, (2) menuliskan kembali/mereproduksi apa yang telah didengar dan dibaca, (3) melakukan kombinasi antara apa yang telah dihafal dan didengar dengan adaptasi kecil, (4) menulis terpimpin, dan (5)menyusun karangan atau komposisi dengan tema, judul, atau topik pilihan siswa sendiri.

Pembelajaran menulis dalam bahasa tidak dapat dilepaskan dari pembelajaran membaca. Pembelajaran menulis merupakan pembelajaran keterampilan penggunaan bahasa dalam bentuk tertulis. Keterampiln menulis adalah hasil dari keterampilan mendengar, berbicara, membaca. Menurut Pirera dan Tasai (1995:27) mengemukakan prinsip prinsip menulis adalah: (1) menulis tidak 
dapat dipisahkan dari membaca. Pada jenjang pendidikan dasar pembelajaran menulis dan membaca terjadi secara serempak, (2) pembelajaran menulis adalah pembelajaran disiplin berpikir dan disiplin berbahasa, (3) pembelajaran menulis adalah pembelajaran tata tulis atau ejaan dan tanda baca bahasa, dan (4) pembelajaran menulis berlangsung secara berjenjang bermula dari menyalin sampai dengan menulis ilmiah.

\section{Menulis Tegak Bersambung}

Kata 'menulis' mempunyai dua arti. Pertama, menulis berarti mengubah bunyi yang dihasilkan oleh alat ucap manusia menjadi tanda-tanda yang dapat dilihat. Kedua, kata 'menulis' mempunyai arti suatu kegiatan mengungkapkan gagasan secara tertulis. Orang yang melakukan kegiatan ini disebut penulis dan hasil kegiatannya berupa tulisan (Rusilah,2006: 6).Henry Guntur Tarigan (2008: 22) menyatakan bahwa pada prinsipnya fungsi utama dari tulisan adalah sebagai alat komunikasi yang tidak langsung. Menulis sangat penting bagi pendidikan karena memudahkan para pelajar berpikir. Juga dapat menolong kita berpikir secara kritis. Juga dapat memudahkan kita merasakan dan menikmati hubunganhubungan, memperdalam daya tanggap atau persepsi kita, memecahkan masalahmasalah yang kita hadapi, menyusun urutan bagi pengalaman. Tulisan dapat membantu kita menjelaskan pikiran-pikiran kita.

Salah satu menulis yang dilakukan di kelas awal terutama kelas 1 adalah menulis tegak bersambung. Tulisan tegak bersambung yang benar tidak sekedar rapi dan indahtetapi juga mudah dibaca. Pada awalnya pasti tidak mudah bagianak-anak untuk menulis huruf tegak bersambung dengan baik danindah. Namun,jika dilatih terus menerus, anak pasti akan semakinterampil. Kegiatan belajar menulis halus untuk anak tidak hanya sekadar agar anak mampu menulis. Terdapat manfaat lainnya yang sangat penting, di antaranya melatih kesabaran, ketelitian, dan melatih motorik halus dan merangsang kerja otak anak. Pola 
menulis yang baik akan berpengaruh terhadap kepribadian anak. Selain itu ada manfaat lain dalam menulis tegak bersambung antara lain, merangsang perkembangan motorik anak, menulis lebih cepat dan tulisan menjadi indah dan rapi. Alasan siswa diberi pelajaran menulis hurufbersambung adalah (1) Tulisan sambung memudahkan siswa untukmengenal kata - kata sebagai satu kesatuan, (2) Menulis tegakbersambung tidak memungkinkan menulis terbalik, (3) Menulistegak bersambung lebih cepat karena tidak ada gerakan berhenti tiaphuruf (Abdurahman, 1999).

Langkah-langkah menulis tegak bersambung di buku tulis halus, yakni (1) memulai menulis dari huruf kecil dengan mengenalkan bentuk baris-baris terlebih dahulu pada siswa dimulai dari tepi bawah baris ke-3, (2) sebelum menulis siswa atau anak harus diperkenalkan huruf mana yang tinggi, menggantung dan memiliki ekor, (3) mengulangi terus menerus sampai hafal dan rapi, dam (4) jika sudah mahir menulis huruf dilanjutkan menulis kata sampai kalimat.

Berikut ini wujud aksara tegak bersambung yang berjumlah 20 aksara.

\section{Teknik Kontrastif dalam Menulis Tegak Bersambung}

Secara umum memahami pengertian analisis kontrastif dapat ditelusuri melalui makna kedua kata tersebut. Analisis diartikan sebagai semacam pembahasan atau uraian. Yang dimaksud dengan pembahasan adalah proses atau cara membahas yang bertujuan untuk mengetahui sesuatu dan memungkmkan dapat menemukan inti permasalahannya. Permasalahan yang ditemukan itu kemudian dikupas, dikritik. diulas, dan akhirnya disimpulkan untuk dipahami Moeliono (1988:32) menjelaskan bahwa analisis adalah penguraian suatu pokok atas berbagai bagiannya dan penelaahan bagian itu sendiri serta hubungan antarbagian untuk memperoleh pengertian yang tepat dan pemahaman arti keseluruhan. Sedangkan kontrastif diartikan sebagai perbedaan atau pertentangan antara dua haI. Perbedaan inilah yang menarik untuk dibicarakan, diteliti. dan 
dipahami. Moeliono menjelaskan bahwa kontrastif diartikan sebagai bersifat membandingkan perbedaan.

Secara khusus analisis kesalahan kontrastif atau lebih populer disingkat anakon adalah kegiatan memperbandingkan struktur bahasa ibu atau bahasa pertama (Bl) dengan bahasa yang diperoleh atau dipelajari sesudah bahasa ibu yang lebih dikenal dengan bahasa kedua (B2) untuk mengidentifikasi perbedaan kedua bahasa tersebut. dalam penelitian ini, yang dibandingkan adalah bentuk atau wujud aksara tegak bersambung. Adapun tabel perbandingan aksaranya adalah sebagai berikut.

\begin{tabular}{lllll} 
Pembeda & Huruf inti & $\begin{array}{l}\text { Huruf } \\
\text { kontras }\end{array}$ \\
\hline Kebalikan & B & D & \\
\hline Jumlah kaki belakang & N & M & \multicolumn{2}{l}{} \\
\hline Berkepala & G & Y & P \\
\hline Jumlah garis & R & G & b & t \\
\hline Panjang ke atas & L & K & b & \\
\hline Panjang ke bawah & Y & & S & v \\
\hline Terpisah & Z & Q & S
\end{tabular}

Dengan dijelaskan berdasarkan konsep berpikir kontranstif, apabila siswa sudah hafal salah satu huruf, maka untuk aksara kontrasnya juga harus tahu. Jika sudah tahu pasti siswa tidak akan terbalik-balik lagi.

Berdasarkan pada tujuan penelitian, yaitu untuk mengetahui penerapan keterampilan menulis tegak bersambung siswa kelas 1 sekolah dasar di Kabupaten Madiun, maka jenis penelitian ini adalah penelitian kualitatif. Penelitian kualitatif adalah penelitian yang prosedur penelitiannya menghasilkan data deskriptif berupa kata-kata tertulis atau lisan yang dapat diamati. Penelitian ini dilaksanakan di SDN Duren 2, Kabupaten Madiun Tahun Pelajaran 2016/2017. Alasan peneliti memilih lokasi ini untuk penelitian yaitu:Sekolah ini memiliki ruang belajar yang nyaman, banyak media-media bantu dalam belajar sehingga 
cukup membantu dalam proses pembelajaran, memiliki siswa yang heterogen sehingga dapat diamati tingkat kemampuan menulis.Objek penelitian ini adalah menulis tegak bersambung dengan teknik kontrastif yang dilakukan dalam pembelajaran bahasa di Sekolah Dasar di Kabupaten Madiun sedangkan subjek penelitiannya adalah guru kelas 1 dan siswa kelas 1 Sekolah Dasar di Kabupaten Madiun, sebab untuk siswa kelas 1 pembelajaran dilaksanakan secara tematis sehingga tidak hanya terfokus pada pembelajaran bahasa. Sesuai dengan asumsi dasar dan data awal maka penelitian ini bertempat di Sekolah Dasar di Kabupaten Madiun.

\section{Metode}

Desain penelitian merupakan uraian tentang pelaksanaan penelitian yang terdiri dari langkah-langkah penelitian mulai dari awal hingga akhir penelitian. Tahap- tahap penelitian ini secara umum dibagi menjadi 3 tahap utama yaitu tahap pra lapangan, tahap pekerjaan lapangan, dan tahap analisis data.

Analisis data kualitatif dilakukan untuk melihat dan menganalisis tulisan siswa ke dalam kategori berdasar deskriptor yang telah dibuat. Menurut Sugiyono (2007:224) teknik pengumpulan data merupakan langkah yang paling strategis dalam penelitian, karena tujuan utama dari penelitian adalah mendapatkan data. Tanpa mengetahui teknik pengumpulan data, maka peneliti tidak akan mendapatkan data yang memenuhi standar data yang ditetapkan.Pada penelitian ini, teknik pengumpulan data yang akan digunakan peneliti adalah dengan metode observasi, tes dankajian Dokumen.

\section{HASIL DAN PEMBAHASAN}

Data yang diperoleh dalam penelitian ini berupa observasi, tes dan kajian dokumen. Observasi dilakukan dengan melihat cara menulis siswa mulai sikap duduk, sikap menulis dan posisi tangan. Dari hasil observasi dapat diketahui 
Nur Samsiyah, Penerapan Teknik... (hlm. 91-103)

bahwa siswa kelas 1 SDN Duren 2 masih banyak yang menulis dengan sikap yang salah. Berikut tabel porsentase siswa berdasarkan hasil observasi.

\begin{tabular}{lll} 
No & Aspek & Porsentase \\
\hline 1 & Sikap duduk & $70 \%$ \\
\hline 2 & Sikap menulis & $65 \%$ \\
\hline 3 & Posisi tangan & $80 \%$ \\
\hline 4 & Cara menulis & $65 \%$
\end{tabular}

Dari tabel di atas dapat dilihat bahwa rata-rata siswa menulis masih menulis dengan sikap yang tidak tepat posisinya. Hal ini ditunjukkan dengan siswa yang menulis dengan tidak sesuai dengan panduan dan arahan dari guru. Ini terjadi karena siswa sudah memiliki kemampuan menulis ketika masih di TK, yang kurang benar, sehingga siswa sudah terbiasa menulis sejak dini dengan sikap yang salah dan cara menulis yang masih sulit dibetulkan.

Tes menulis dilakukan dengan menggunakan tulisan berbentuk huruf yang sesuasi dengan bentuk tulisan tegak bersambung. Tujuan dari tes adalah untuk mengetahui bagaimana gambaran penerapan menulis siswa dalam menulis tegak bersambung menggunakan teknik konstraktif. Dalam hal ini tes dibuat dalam bentuk uraian dengan tujuan peneliti dapat mengetahui langkah-langkah yang diambil subyek dalam menyelesaikan soal tes. Tes yang digunakan adalah tes menulis huruf sesuai dengan tabel bentuk tulisan tegak bersambung. 


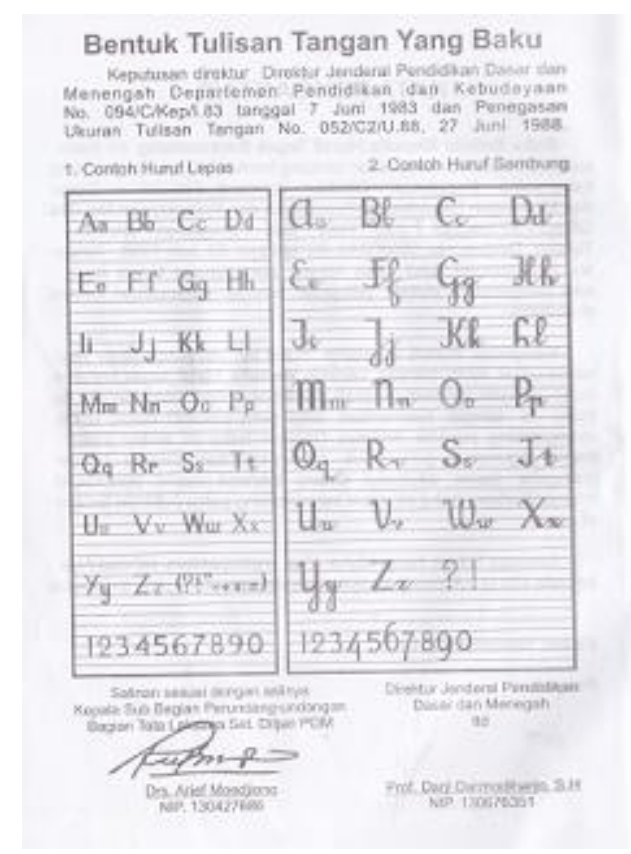

Huruf tegak bersambung sesuai SK Dirjen Dikdasmen Kemdikbud

Dari hasil tes ini kemudian peneliti menganalisis jawaban dari masingmasing subyek. Setelah tes selesai dianalisis, peneliti mengadakan kajian dokumen dengan subyek terkait dengan jawaban dari tes. Berikut adalah hasil tes dari siswa kelas 1

\begin{tabular}{cccc} 
No & $\begin{array}{c}\text { Kemampuan menggunakan } \\
\text { siswa } \\
\text { ejaan (penggunaan huruf } \\
\text { kapital, tanda baca) }\end{array}$ & $\begin{array}{c}\text { Kemampuan menulis } \\
\text { dengan rapi (bersih, } \\
\text { rapi, sesuai huruf tegak } \\
\text { bersambung) }\end{array}$ & $\begin{array}{c}\text { Kemampuan teknik } \\
\text { konstraktif (penggunaan } \\
\text { perbandingan, huruf mirip, } \\
\text { huruf berbeda) }\end{array}$ \\
\hline 1 & 80 & Nilai & 100 \\
\hline 2 & 85 & 80 & 80 \\
\hline 3 & 80 & 85 & 90 \\
\hline 4 & 80 & 80 & 90 \\
\hline 5 & 80 & 80 & 90
\end{tabular}

100 | http://journal.unesa.ac.id/index.php/paramasastra 
Nur Samsiyah, Penerapan Teknik... (hlm. 91-103)

\begin{tabular}{cccc}
6 & 90 & 80 & 100 \\
\hline 7 & 90 & 80 & 100 \\
\hline 8 & 70 & 60 & 80 \\
\hline 9 & 80 & 90 & 100 \\
\hline 10 & 80 & 70 & 90 \\
\hline 11 & 80 & 70 & 90 \\
\hline 12 & 90 & 80 & 90 \\
\hline 13 & 90 & 90 & 90 \\
\hline 14 & 90 & 80 & 92,4 \\
\hline Rata- & 83,2 & 79,6 &
\end{tabular}

Dari data tes menunjukkan siswa telah mengenal huruf abjad secara benar. Hal itu diketahui dari rata-rata nilai siswa setelah dilakukan tes menulis mendapat nilai 83,2. Sedangkan kerapian rata-rata siswa mendapat nilai 79,6. Dengan menggunakan teknik konstraktif siswa lebih mudah mengenal huruf dengan mencari perbandingan dan persamaan, sehingga siswa hanya menghafal jenis huruf misalnya huruf yang panjang ke atas dibandingkan dengan yang panjang ke bawah. Huruf yang berbalik misalnya b dengan d. Hal ini mempermudah siswa menuliskannya. Huruf yang memiliki jambul, misalnya $b, h, k, l$, dan $d, t$. Huruf yang memiliki ekor, misalnya $g, j, y, p$, dan $q$. Huruf yang tidak memiliki ekor dan jambul, misalnya $a, c, e, i, m, n, \sigma, r, \delta, w, v, w, x$, $\operatorname{dan} z$

Menulis huruf tegak bersambung atau menulis halus memiliki banyak manfaat bagi anak-anak. Ketika anak menulis dengan tangan, sensori motorik halus, sentuhan, dan visual anak akan aktif secara bersamaan. Proses penggoresan 
garis tegak yang tebal dan garis miring yang tipis pada huruf tegak bersambung melatih anak tentang ketegasan, kelembutan, dan ketekunan. Karena itu, sekalipun zaman sudah serba komputer dan digital, tidak ada salahnya kita tetap mengajarkan anak cara menulis huruf tegak bersambung.Tidak susah mengajari anak menulis halus, hanya dibutuhkan ketekunan berlatih dan suasana belajar yang menyenangkan. Secara teknis, pembelajaran bisa dimulai dari menjiplak, meniru, lalu menulis ulang tulisan biasa menjadi tulisan tegak bersambung. Secara materi, bisa dimulai dari menulis huruf tunggal, satu suku kata, satu kata, dan satu kalimat. Untuk menjiplak dan meniru, kita bisa menggunakan buku-buku yang berisi latihan menulis halus.Anak-anak kelas 1, 2, dan 3 menulis huruf tegak bersambung harus mengikuti aturan yang benar. Siswa dapat belajar menulis huruf tegak bersambung melalui pedoman yang telah ditetapkan oleh kementerian pendidikan dan kebudayaan. Siswa juga dapat berlatih menulis sambil membaca bahan yang akan ditulis. Hal ini sejalan dengan pendapat Menurut Pirera dan Tasai (1995:27) mengemukakan prinsip prinsip menulis adalah: (1) menulis tidak dapat dipisahkan dari membaca. Pada jenjang pendidikan dasar pembelajaran menulis dan membaca terjadi secara serempak, (2) pembelajaran menulis adalah pembelajaran disiplin berpikir dan disiplin berbahasa, (3) pembelajaran menulis adalah pembelajaran tata tulis atau ejaan dan tanda baca bahasa, dan (4) pembelajaran menulis berlangsung secara berjenjang bermula dari menyalin sampai dengan menulis ilmiah.

\section{DAFTAR PUSTAKA}

Abdurrahman,Mulyono. 1999. Pendidikan Bagi Anak Berkesulitan Belajar. Jakarta: RinekaCipta.

Ahmadi, M. 1988. Materi Dasar Pengajaran Komposisi Bahasa Indonesia. Jakarta: Depdikbud. 
Nur Samsiyah, Penerapan Teknik... (hlm. 91-103)

Alex dan Achmad H.P. 2011. Bahasa Indonesia untuk Perguruan Tinggi. Jakarta: Kencana.

Akhadiyah. 1990. Pembinaan Kemampuan Menulis Bahasa Indonesia. Jakarta: Depdikbud.

Anonymous. 2009. Standar Proses untuk Satuan Pendidikan Dasar dan Menengah Permendiknas Republik Indonesia no.41 tahun 2007. Online (diakses pada 17 Juni 2017). www.Google. Com

Arikunto, Suharsimi. 2012. Prosedur Penelitian Suatu pendekatan Praktek. Jakarta: Rineka Cipta

Depdiknas. 2006. Standar Isi Untuk Satuan Pendidikan Dasar dan Menengah. Jakarta: Depdiknas

Hamalik, Oemar. 2001. Perencanaan Pengajaran Berdasarkan Pendekatan Sistem. Bandung: Bumi Aksara

Haryadi dan Zamzami. 1996. Peningkatan Keterampilan Berbahasa Indonesia. Jakarta: Depdikbud Dikti

Santoso, Puji. 2008. Materi dan Pembelajaran Bahasa Indonesia SD. Jakarta: Universitas Terbuka

Suparno. 2002. Keterampilan Dasar Menulis. Jakarta: DepdiknasUT

Soedjito dan Hasan, M. 1986. Seri Membina Keterampilan Menulis Paragraf. Malang: Tanpa Penerbit

Syafi'ie, I. 1988. Retorika dalam Menulis. Jakarta: Depdikbud.

Tarigan, H.G. 2008. Menulis sebagai Suatu Keterampilan Berbahasa. Bandung: Angkasa

Zuhdi, dkk. 2008. Cara Menulis Buku. Malang: Rena Press.

http://www.spirit-guru.com/2016/04/belajar-menulis-tegak-bersambung.html diakses tanggal 3 Juli 2017

http://journal.unesa.ac.id/index.php/paramasastra | 103 
PARAMASASTRA, Vol. 5, No. 1-Maret 2018

104 | http://journal.unesa.ac.id/index.php/paramasastra 